\title{
U11/U12 Small Nuclear Ribonucleoprotein 25 kDa Protein
}

National Cancer Institute

\section{Source}

National Cancer Institute. U11/U12 Small Nuclear Ribonucleoprotein 25 kDa Protein. NCI

Thesaurus. Code C134681.

U11/U12 small nuclear ribonucleoprotein $25 \mathrm{kDa}$ protein (132 aa, $15 \mathrm{kDa}$ ) is encoded by the human SNRNP25 gene. This protein plays a role in the removal of U2- and U12-type introns from pre-mRNAs. 